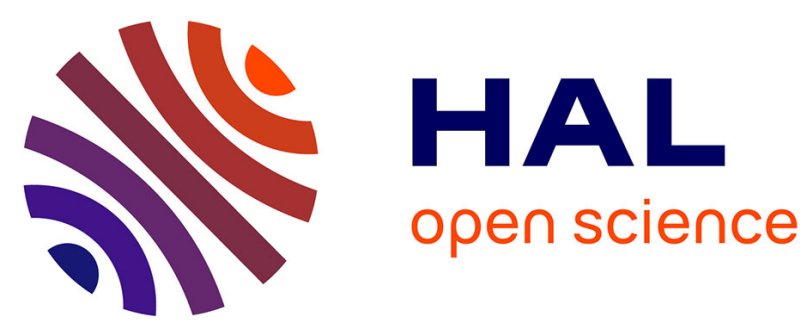

\title{
Cost Effectiveness of Intra-Articular Hyaluronic Acid and Disease-Modifying Drugs in Knee Osteoarthritis
}

\author{
Jean-Hugues Salmon, Anne-Christine Rat, Isabelle Charlot-Lambrecht, \\ Jean-Paul Eschard, Damien Jolly, Bruno Fautrel
}

\section{- To cite this version:}

Jean-Hugues Salmon, Anne-Christine Rat, Isabelle Charlot-Lambrecht, Jean-Paul Eschard, Damien Jolly, et al.. Cost Effectiveness of Intra-Articular Hyaluronic Acid and Disease-Modifying Drugs in Knee Osteoarthritis. PharmacoEconomics, 2018, 36 (11), pp.1321 - 1331. 10.1007/s40273-018-06955. hal-03584953

\section{HAL Id: hal-03584953 \\ https://hal.science/hal-03584953}

Submitted on 1 Mar 2022

HAL is a multi-disciplinary open access archive for the deposit and dissemination of scientific research documents, whether they are published or not. The documents may come from teaching and research institutions in France or abroad, or from public or private research centers.
L'archive ouverte pluridisciplinaire HAL, est destinée au dépôt et à la diffusion de documents scientifiques de niveau recherche, publiés ou non, émanant des établissements d'enseignement et de recherche français ou étrangers, des laboratoires publics ou privés. 


\title{
Cost effectiveness of intra-articular hyaluronic acid and disease modifying drugs in knee osteoarthritis
}

\author{
JH Salmon ${ }^{1,2}$, AC Rat $^{3,4}$, I Lambrecht $^{1}$, JP Eschard $^{1}$, D Jolly ${ }^{2,5}$, B Fautrel ${ }^{6}$ \\ ${ }^{1}$ Rheumatology Department, Maison Blanche Hospital, Reims University Hospitals, Reims, F-51092, France. \\ ${ }^{2}$ University of Reims Champagne-Ardenne, Faculty of Medicine, EA 3797, REIMS, F-51095, France. \\ ${ }^{3}$ Rheumatology Department, CHRU de Nancy, Hôpitaux de Brabois, Vandoeuvre-lès-Nancy, France. \\ ${ }^{4}$ Université de Lorraine, APEMAC, F-54000 Nancy, France ; INSERM, CIC-EC 1433, 54000 Nancy, France. \\ ${ }^{5}$ Department of Research and Innovation, Robert Debré Hospital, Reims University Hospitals, Reims, F-51092, \\ France. \\ ${ }^{6}$ Sorbonne Université, Institut Pierre Louis de d'Epidémiologie et Santé Publique, GRC08; AP-HP, Pitié- \\ Salpêtrière Hospital, Rheumatology Department, 83 Boulevard de l'Hôpital, 75013, Paris, France.
}

jhsalmon@chu-reims.fr, ac.rat@chu-nancy.fr, ilambrecht@chu-reims.fr jpeschard@chu-reims.fr, djolly@chureims.fr, bruno.fautrel@psl.aphp.fr

Correspondence and reprint requests to: Dr Jean-Hugues SALMON, Rheumatology Department, Maison Blanche Hospital, Reims University Hospitals, Reims, F-51092, France

Running title: Cost-effectiveness in knee osteoarthritis 


\section{Abstract (239 words)}

Background: The place of disease modifying osteoarthritis drugs and intra-articular hyaluronic acid in the therapeutic arsenal of knee osteoarthritis remains uncertain. Indeed, these treatments have demonstrated symptomatic efficacy but no efficacy for disease modification.

Objective: This report reviews the cost effectiveness of intra-articular hyaluronic acid (IAHA) and disease modifying osteoarthritis drugs (DMOADs) used in the treatment of knee osteoarthritis.

Methods: A systematic literature search of MEDLINE, Scopus, EMBASE and Cochrane databases for articles was performed independently by 2 rheumatologists who used the same predefined eligible criteria. Papers without abstracts and in languages other than English or French were excluded. Extracted costs were annualized and converted to 2015 euros $(€)$ by using the Consumer Price Index of the relevant countries and the 2013 Purchasing Power Parities between these countries and the European Union average.

Results: A total of 95 abstracts were selected, and 13 articles were considered for the review. Nine articles were on IAHA and 4 articles on DMOADs. Only one article directly compared different IAHA compound. Articles showed substantial heterogeneity in methodological approaches. The incremental cost-effectiveness ratios (ICER) ranged from 4,000 to 57,550€ and from 240 to 53,225€ per QALY gained for DMOADs and IAHA respectively.

\section{Conclusions:}

This review highlights substantial heterogeneity between studies, ranging from cost saving (or dominating) position to very high ICERs, far above the acceptability threshold of 50,000 €/QALY. Additional research is needed to display reliable and robust ICER estimates for knee OA therapies.

Keywords: Osteoarthritis, Cost-effectiveness, Hip, Knee, Systematic review

Word count: 2222

\section{Key points}

- The position of disease modifying osteoarthritis drugs (DMOADs) and intra-articular hyaluronic acid (IAHA) in the therapeutic arsenal of knee osteoarthritis remains debated.

- This review highlights substantial heterogeneity: a multiplication factor of 14-fold (DMOADs) and 175-fold (IAHA) between the lowest and highest ICER estimate.

- Additional research is needed to display reliable and robust ICERs for these knee osteoarthritis therapies. 


\section{Introduction}

Osteoarthritis is the most frequent or prevalent chronic joint disease and a major contributor to functional disability and loss of autonomy in older adults [1]. OA has become a research priority in the European Community (Horizon 2020 Framework Programme) [3]. Hip and knee OA causes the greatest burden to the population in terms of pain, stiffness and disability, thereby leading to the need for prosthetic joint replacement for the most severe cases [4]. The burden to society is expected to be high because of the prevalence of symptomatic knee OA (prevalence of $10 \%$ to $20 \%$ ) [5-11].

According to the OA Research Society International, disease management of knee OA included nonpharmacological treatment (weight management, exercise, strength training) and pharmacological treatment (NSAIDs, acetaminophen, duloxetine and intra-articular corticosteroids) [12]. These treatments mainly aim at alleviating symptoms improve functional capacity and potentially postpone the time for prosthesis surgery. Other therapies exist to treat the symptoms of knee OA patients such as disease modifying osteoarthritis drugs (DMOADs) and intra-articular hyaluronic acid (IAHA). However, their position in the therapeutic arsenal remains debated [12-14]. Indeed, these treatments have demonstrated some symptomatic efficacy but no real efficacy for disease modification [12].

For the therapies with significant health benefit but additional cost to the health system, cost-effectiveness evaluation are needed to provide valuable information to clinicians and decision makers about whether the provision of the treatment is an efficient and fair way to allocate resources - unavoidably limited - for the overall improvement of population health. We aimed to review the cost-effectiveness analyses of DMOADs and IAHA for knee OA

\section{Methods}

\section{Research question and literature search}

We performed a systematic search of articles in, MEDLINE via PubMed, Scopus, EMBASE and Cochrane databases across the period from 1966 to May 2018. We used the Participants, Interventions, Comparisons and Outcomes (PICO) strategy for the research question as follows: population, knee OA; intervention, IAHA or DMOADs; control, others treatments and no treatment OA; and outcome, incremental cost per QALY gained [15]. The algorithm used to search article titles, abstracts and key words were ("Osteoarthritis"[Mesh]) AND 
"Cost-Benefit Analysis"[Mesh]) for MEDLINE, (Cost-Effectiveness AND Osteoarthritis) for Scopus, (CostEffectiveness AND Knee Osteoarthritis) for EMBASE and (Cost AND Osteoarthritis) for the Cochrane database.

\section{Article selection}

The titles and abstracts of all articles identified were independently screened by 2 rheumatologists (JHS and IL) who used predefined criteria to identify relevant articles; disagreements were resolved by consensus. Abstracts were excluded if 1) data focused on NSAIDs, analgesics, non-pharmacological treatment or surgical procedures, 2) no cost-effectiveness data were reported, 3) no primary data were reported (e.g., literature review), 5) abstracts from conferences, symposia or scientific meetings were not considered (Figure 1). The full texts of the remaining articles were then retrieved. We excluded articles that had insufficient, imprecise or incomplete data (e.g., indirect costs only, lack of direct cost breakdown) and uncontrolled before-after studies. We used the Cochrane Collaboration tool for the assessment of risk of bias [16] to evaluate the quality of the RCT studies included in this systematic review according to the level of bias risk (supplemental data).

\section{Data extraction}

Data extracted were the following: study parameters, i.e., type of model, sample size, country of the study and sponsor (academic or pharma industry); treatment characteristics, i.e., International Nonproprietary Names (INN), commercial name to differentiate compounds with the same INN (IAHA), dosage, duration; clinical outcomes, i.e., pain based on visual analogue scale (VAS), function based on Western Ontario and McMaster Universities Osteoarthritis Index (WOMAC) [17] or SF-12 Health Survey [18] and health gain based on Health Utilities Index 3 (HUI 3) [19,20] or EQ-5D Instruments [21] and expressed in quality-adjusted life years (QALY).

Treatment costs were extracted from articles that described assessing them from a payer or societal perspective. In addition, Incremental cost-effectiveness ratios (ICER) were included when available. This ratio relates the difference in costs between a medicine and the comparator to the difference in outcomes. There were valued as the cost per QALY gained. Extracted or elicited costs were converted to an annual cost and to 2017 euros (€) by using the Consumer Price Index of the relevant countries and the 2017 Purchasing Power Parities (Organization for Economic Cooperation and Development, www.oecd.org) between these countries [22]. 


\section{Results}

\section{Literature search}

We obtained 95 article titles with abstracts through the meta-search, and 20 abstracts were selected. The assessment of full texts resulted in 13 articles selected for the review (Figure 1): four concerned DMOADs and nine IAHA [23-35]. Two articles were excluded because of their design : that was observational multicentre non controlled before-after studies [36,37]. One non randomized case control study was included since the two study groups were comparable as baseline in turn of (age, sex, WOMAC, quality of life, Radiological stage) [35].

\section{Selected studies}

The 13 articles were heterogeneous (Table 1). Study design were model simulation of knee OA (n=4) [26,28,30,31], randomized clinical trial $(n=8)[23-25,27,29,32-34]$ or case control study $(n=1)$ [35]. Sample sizes varied from 37 to 1,000 . Control group were usual care $(n=8)[23,26,27,30-34]$ or imposed care $(n=5)$ $[24,25,28,29,35]$. Different perspectives have been used to evaluate costs: perspective was societal $(n=6)[23,27-$ $29,31,33]$ or payer $(n=7)[24-26,30,32,34,35]$. Studies were conducted in Europe $(n=5)[23,25,33-35]$, North America $(n=4)$, South America $(n=1)$ [31] [26,27,30,32], Asia $(n=2)[28,29]$ and multi-continental study $(n=1)$ [24]. Periods of publication were 1995-2000 ( $n=2), 2000-2005(n=2), 2005-2010(n=3)$, and after $2010(n=6)$. Treatment characteristics were not specified in one study [26]. Because of substantial heterogeneity, no pooling was possible and only descriptive results could be presented. The quality of RCT studies was evaluated according to the level of bias risk (supplemental data).

\section{Patient characteristics}

All articles described symptomatic OA patients. Most studies included OA patients based on ACR criteria [38,39], with radiographic criteria. Twelve articles included only knee OA patients and 1 article included knee and hip OA patients. The median patient follow-up in trial based studies was 9 months (interquartile range [IQR] 6-12). The mean age was reported in all studies: mean $64 \pm 5$ years (median 63, IQR 62-66).

\section{Cost-effectiveness estimates for DMOADs (Table 2)}

The variation in cost between the treatment group and the control group varies between $10 €$ and 2,300 $€$. The variation in incremental effectiveness between the treatment group and the control group varies between 0.01 and 0.025 QALY. ICERs varies between 4,000 to 57,550€ per QALY gained [25,26]. In RCT studies, ICERs 
was 4,000€ per QALY gained [25]. In simulation model studies, ICERs was 57550€ per QALY gained [26]. Two studies had a negative ICER [23,25], in both cases it was dominant (less expensive and more effective).

\section{Cost-effectiveness estimates for IAHA (Table 2)}

The variation in cost between the treatment group and the control group varies between $0 €$ and $955 €$. The variation in incremental effectiveness between the treatment group and the control group varies between 0.0031 and 0.115 QALY. ICERs varies between 240 to 53,225€ per QALY gained. Among academic studies, ICERs yielded a broader range of ICERs, from 10,195 to 53,225€ [27-29,33], compared to industry-sponsored studies, with values from 240 to $39,375 €$ per QALY gained [30-32,34,35]. The ICER estimates also varied with the model time frame. For studies with 6 months follow-up, ICERs ranged from 240 to 53,225€ per QALY gained. For studies with 12 months follow-up, ICERs ranged between 10,195 to 39,375€ per QALY gained. Only one lifetime modeling beyond the trials were performed, allowing the integration of the possible long term benefits of the treatments [31]. In RCT studies, ICERs varies between 4,390 to 13,450€ per QALY gained [27,29,32-34]. In simulation model study, ICERs varies between 305 to 53,225€ per QALY gained [28,30,31]. For the studies using "usual care" (NSAID, physiotherapy and paracetamol) as control treatment, ICER ranged from 4,390 to $39,375 €$ per QALY gained [27,30-34]. For studies with payers perspective, ICERs ranged between 240 to 39,375€ per QALY gained [30,32,34,35]. For studies with societal perspective, ICERs ranged between 305 to 53,225€ per QALY gained [27-29,31,33]. One study had a negative ICER with a dominance (less expensive and more effective) [29].

\section{Discussion}

We performed a systematic review of the literature of cost-effectiveness analysis of DMOADs and IAHA in knee OA. Depending on the type of study (trial-based or model-based), the control group and the duration of follow-up, OA articles reported different ICER estimates, with a multiplication factor of 14-fold (DMOADs) and 222-fold (IAHA) between the lowest and highest ICER estimate.

Several sources of heterogeneity could be mentioned and taken into account when interpreting the results of this review. The sample size of the trial: The economic appraisal should be factored into sample size calculations. However, it is common for the sample size of the trial, to be based on primary clinical outcomes alone. As a consequence, the economic comparisons can be underpowered [40,41]. There was also an issue with time horizon. The median patient follow-up was short. Indeed, clinical trials rarely extend beyond a few years and are 
often conducted over much shorter periods [40,41]. Yet, OA is a chronic disease, a lifetime horizon is most often appropriate and some long term benefits of the treatments, e.g. reduction in joint prosthesis need, were not estimated [42]. A third source of heterogeneity was the nature of the control group - placebo versus usual care may maximize the incremental cost-effectiveness due to the higher effect size of the intervention compared to the placebo (PMID : 20228282)[43]- Fourthly, the perspective may differ between the studies. In cost-benefit analysis, societal perspective should be the preferred method over the health care or payer perspective. A costbenefit analysis accounting for all the societal benefits and costs enable more reliable and transparent decisions taken by policy-makers, especially in chronic diseases in which patients, family members and caregivers are often largely impacted [44]. Conversely NICE recommends the use of the payer perspective, i.e., the perspective of the National Health Service and personal and social services', focusing on direct costs and avoiding potential biases against non at-work people in the indirect cost elicitation [45].

Finally, the impact of the study sponsor should be mentioned. The primary objectives of research and development clearly differ between industry and academics [46]. The two types of research should not be opposed, but should take the form of a constructive collaboration, increasing the chances of reaching each individual goal [47]. In our review, all ICER estimates of industry-sponsored studies fell within the "acceptable" ICER range (0 to 50,000 €/QALY), although those from academic studies did not always.

No DMOADs cost-effectiveness studies were identified in the published literature. A model to assess costeffectiveness was constructed using cohort simulation for glucosamine [48], resulting in a dominant position for this agent. This estimate was particularly dependent on the magnitude of the quality of life gain and clearly lacks of robustness (48). The cost effectiveness of IAHA has been studied in a limited number of review articles which suggest that IAHA may be cost effective compared with usual care [49-51]. The only 3 reviews included two, 1 and 10 articles respectively. The present study brings additional and more comprehensive information, including six recent articles not included in previous metanalysis and providing more robust conclusions [29-33,35].

OA definition is also a quite challenging field for such research. There is a lack of consensus for OA definition. Variable definitions of knee OA can be used - clinical, radiological or both [52,53]. Actually, from a public health perspective, a diagnosis based on both clinical and radiological features is recommended [52]. In addition, some authors recently suggested separating OA by phenotypes, reflecting different risk factors, comorbidities and potentially pathogenic pathways [54,55]. Comorbidities such as obesity are closely related with knee OA [56]. These data were not systematically collected in clinical trials, and usually not collected or analyzed in 
administrative databases which could be an alternative source of data for economic modelling. In the present work, we could not assess this new "view" of OA because the reviewed articles did not provide enough details on medical history or comorbidities. However, integrating these phenotypic specificities in future epidemiological and economic analyses will be interesting; such phenotypes could have substantial impact on Quality Adjusted Life Year, thereby resulting in major differences in cost estimates.

Finally, there is a lack consensus for economic modelization up to recent years [42,57]. Recently, a reference case for economic assessment in osteoarthritis was proposed[42], but never implemented since then. In addition, there is a need for cost-effectiveness threshold to state whether the health benefits are worth the financial investment because the additional resources required are not available to fund other effective treatments. This cost-effectiveness threshold will vary from country to country. [26] : in the UK values of $220,000-$ 30,000/QALY (approximately 50,000 €/QALY) are typically used, although it is 80,000 €/QALY in The Netherlands [58]. However, there is a lack of understanding about what thresholds mean and their implications [59][60-62].

\section{Conclusion}

In conclusion, the results of this systematic literature review indicate there is substantial uncertainty for DMOADs and IAHA ICER estimates due to heterogeneity of studies. ICER of industry-sponsored studies are clearly favorable than those of academic studies. For this reason, it appears difficult to conclude that these treatments are cost-effective in the management of osteoarthritis of the knee with the commonly accepted thresholds. Additional research is needed to display reliable and robust ICER estimates for knee OA therapies. 
Data Availability Statement: Authors can confirm that all relevant data are included in the article and/or its supplementary information files

Competing interests: Author disclosures of honoraria for advice or public speaking, grants received and/or advisory board participation are as follows:

JHS: Jean Hugues Salmon has received consultancy fees from Abbvie, BMS, Janssen, Lilly, MSD, Novartis, Pfizer, Roche, UCB

ACR:None

ICL: Isabelle Charlot-Lambrecht has received consultancy fees from Amgen, MSD

JPE: Jean Paul Eschard has received consultancy fees from Abbvie, BMS, Janssen, Lilly, MSD, Novartis, Pfizer, Roche, Sanofi, UCB

DJ: None

BF: Bruno Fautrel has received research grants from AbbVie, Lilly, MSD and Pfizer, and consultancy fees from AbbVie, Biogen, BMS, Celgene, Janssen, Lilly, Medac, MSD, NORDIC Pharma, Novartis, Pfizer, Roche, Sanofi-Aventis, SOBI, UCB

Authors' contributions: The design of the study was conceived by JHS, BF, and DJ. Data collection, management and analysis were performed by JHS and BF. All authors participated in the interpretation of the results and manuscript writing. All have read and approved the final version of the manuscript for publication.

\section{Funding: None}

\section{Conflict of interest:}

Bruno Fautrel has received research grants from AbbVie, Lilly, MSD and Pfizer, and consultancy fees from AbbVie, Biogen, BMS, Celgene, Janssen, Lilly, Medac, MSD, NORDIC Pharma, Novartis, Pfizer, Roche, Sanofi-Aventis, SOBI, UCB. Jean Paul Eschard has received consultancy fees from Abbvie, BMS, Janssen, Lilly, MSD, Novartis, Pfizer, Roche, Sanofi, UCB. Jean Hugues Salmon has received consultancy fees from Abbvie, BMS, Janssen, Lilly, MSD, Novartis, Pfizer, Roche, UCB. Isabelle Charlot-Lambrecht has received consultancy fees from Amgen, MSD 
1. Felson DT, Zhang Y, Hannan MT, Naimark A, Weissman BN, Aliabadi P, et al. The incidence and natural history of knee osteoarthritis in the elderly. The Framingham Osteoarthritis Study. Arthritis Rheum. 1995;38:1500-5.

2. Vos T, Flaxman AD, Naghavi M, Lozano R, Michaud C, Ezzati M, et al. Years lived with disability (YLDs) for 1160 sequelae of 289 diseases and injuries 1990-2010: a systematic analysis for the Global Burden of Disease Study 2010. Lancet. 2012;380:2163-96.

3. Horizon 2020 - European Commission [Internet]. Horiz. 2020. [cited 2015 Apr 13]. Available from: http://ec.europa.eu/programmes/horizon2020/

4. Litwic A, Edwards MH, Dennison EM, Cooper C. Epidemiology and burden of osteoarthritis. Br Med Bull. 2013;105:185-99.

5. Guillemin F, Rat AC, Mazieres B, Pouchot J, Fautrel B, Euller-Ziegler L, et al. Prevalence of symptomatic hip and knee osteoarthritis: a two-phase population-based survey. Osteoarthr Cartil OARS Osteoarthr Res Soc. 2011;19:1314-22.

6. Jordan JM, Helmick CG, Renner JB, Luta G, Dragomir AD, Woodard J, et al. Prevalence of knee symptoms and radiographic and symptomatic knee osteoarthritis in African Americans and Caucasians: the Johnston County Osteoarthritis Project. J Rheumatol. 2007;34:172-80.

7. Jordan JM, Helmick CG, Renner JB, Luta G, Dragomir AD, Woodard J, et al. Prevalence of hip symptoms and radiographic and symptomatic hip osteoarthritis in African Americans and Caucasians: the Johnston County Osteoarthritis Project. J Rheumatol. 2009;36:809-15.

8. Andrianakos AA, Kontelis LK, Karamitsos DG, Aslanidis SI, Georgountzos AI, Kaziolas GO, et al. Prevalence of symptomatic knee, hand, and hip osteoarthritis in Greece. The ESORDIG study. J Rheumatol. 2006;33:2507-13.

9. Salaffi F, De Angelis R, Grassi W, MArche Pain Prevalence, INvestigation Group (MAPPING) study. Prevalence of musculoskeletal conditions in an Italian population sample: results of a regional community-based study. I. The MAPPING study. Clin Exp Rheumatol. 2005;23:819-28.

10. Grotle M, Hagen KB, Natvig B, Dahl FA, Kvien TK. Prevalence and burden of osteoarthritis: results from a population survey in Norway. J Rheumatol. 2008;35:677-84.

11. Principaux tableaux - Eurostat [Internet]. [cited 2015 Jul 24]. Available from: http://ec.europa.eu/eurostat/web/population-demography-migration-projections/populationdata/main-tables

12. McAlindon TE, Bannuru RR, Sullivan MC, Arden NK, Berenbaum F, Bierma-Zeinstra $\mathrm{SM}$, et al. OARSI guidelines for the non-surgical management of knee osteoarthritis. Osteoarthritis Cartilage. 2014;22:363-88.

13. Brown GA. AAOS clinical practice guideline: treatment of osteoarthritis of the knee: evidence-based guideline, 2nd edition. J Am Acad Orthop Surg. 2013;21:577-9. 
14. Bruyère $\mathrm{O}$, Cooper $\mathrm{C}$, Pelletier J-P, Maheu E, Rannou F, Branco J, et al. A consensus statement on the European Society for Clinical and Economic Aspects of Osteoporosis and Osteoarthritis (ESCEO) algorithm for the management of knee osteoarthritis-From evidencebased medicine to the real-life setting. Semin Arthritis Rheum. 2016;45:S3-11.

15. PICO ontology | Cochrane Linked Data (beta) [Internet]. [cited 2015 Sep 3]. Available from: http://linkeddata.cochrane.org/pico-ontology

16. Cochrane Handbook for Systematic Reviews of Interventions [Internet]. [cited 2018 May 7]. Available from: http://handbook-5-1.cochrane.org/

17. Bellamy N, Buchanan WW, Goldsmith CH, Campbell J, Stitt LW. Validation study of WOMAC: a health status instrument for measuring clinically important patient relevant outcomes to antirheumatic drug therapy in patients with osteoarthritis of the hip or knee. J Rheumatol. 1988;15:1833-40.

18. Gandek B, Ware JE, Aaronson NK, Apolone G, Bjorner JB, Brazier JE, et al. Crossvalidation of item selection and scoring for the SF-12 Health Survey in nine countries: results from the IQOLA Project. International Quality of Life Assessment. J Clin Epidemiol. 1998;51:1171-8.

19. Grootendorst P, Marshall D, Pericak D, Bellamy N, Feeny D, Torrance GW. A model to estimate health utilities index mark 3 utility scores from WOMAC index scores in patients with osteoarthritis of the knee. J Rheumatol. 2007;34:534-42.

20. Horsman J, Furlong W, Feeny D, Torrance G. The Health Utilities Index (HUI): concepts, measurement properties and applications. Health Qual Life Outcomes. 2003;1:54.

21. Devlin NJ, Brooks R. EQ-5D and the EuroQol Group: Past, Present and Future. Appl Health Econ Health Policy. 2017;15:127-37.

22. Consumer Prices (MEI) [Internet]. [cited 2015 Apr 13]. Available from: http://stats.oecd.org/Index.aspx?DatasetCode=MEI_PRICES

23. Fagnani F, Bouvenot G, Valat JP, Bardin T, Berdah L, Lafuma A, et al. Medico-economic analysis of diacerein with or without standard therapy in the treatment of osteoarthritis. PharmacoEconomics. 1998;13:135-46.

24. Bruyère O, Scholtissen S, Neuprez A, Hiligsmann M, Toukouki A, Reginster JY. Impact of chondroitin sulphate on health utility in patients with knee osteoarthritis: towards economic analysis. J Med Econ. 2009;12:356-60.

25. Scholtissen S, Bruyère O, Neuprez A, Severens JL, Herrero-Beaumont G, Rovati L, et al. Glucosamine sulphate in the treatment of knee osteoarthritis: cost-effectiveness comparison with paracetamol. Int J Clin Pract. 2010;64:756-62.

26. Losina E, Daigle ME, Suter LG, Hunter DJ, Solomon DH, Walensky RP, et al. Diseasemodifying drugs for knee osteoarthritis: can they be cost-effective? Osteoarthritis Cartilage. 2013;21:655-67.

27. Torrance GW, Raynauld JP, Walker V, Goldsmith CH, Bellamy N, Band PA, et al. A prospective, randomized, pragmatic, health outcomes trial evaluating the incorporation of 
hylan G-F 20 into the treatment paradigm for patients with knee osteoarthritis (Part 2 of 2): economic results. Osteoarthritis Cartilage. 2002;10:518-27.

28. Yen Z-S, Lai M-S, Wang C-T, Chen L-S, Chen S-C, Chen W-J, et al. Cost-effectiveness of treatment strategies for osteoarthritis of the knee in Taiwan. J Rheumatol. 2004;31:1797803.

29. Chou C-W, Lue K-H, Lee H-S, Lin R-C, Lu K-H. Hylan G-F 20 has better pain relief and cost-effectiveness than sodium hyaluronate in treating early osteoarthritic knees in Taiwan. $\mathrm{J}$ Formos Med Assoc Taiwan Yi Zhi. 2009;108:663-72.

30. Hatoum HT, Fierlinger AL, Lin S-J, Altman RD. Cost-effectiveness analysis of intraarticular injections of a high molecular weight bioengineered hyaluronic acid for the treatment of osteoarthritis knee pain. J Med Econ. 2014;17:326-37.

31. Castro J-C, Daza A-M, Misas J-D. Cost-effectiveness Analysis of Viscosupplementation versus Conventional Supportive Therapy for Knee Osteoarthritis in Colombia. Value Health Reg Issues. 2015;8:56-61.

32. Rosen J, Sancheti P, Fierlinger A, Niazi F, Johal H, Bedi A. Cost-Effectiveness of Different Forms of Intra-Articular Injections for the Treatment of Osteoarthritis of the Knee. Adv Ther. 2016;33:998-1011.

33. Hermans J, Reijman M, Goossens LMA, Verburg H, Bierma-Zeinstra SMA, Koopmanschap MA. Cost-Utility Analysis of High Molecular Weight Hyaluronic Acid for Knee Osteoarthritis in Everyday Clinical Care in Patients at a Working Age: An Economic Evaluation of a Randomized Clinical Trial. Arthritis Care Res. 2018;70:89-97.

34. Kahan A, Lleu P-L, Salin L. Prospective randomized study comparing the medicoeconomic benefits of Hylan GF-20 vs. conventional treatment in knee osteoarthritis. Jt Bone Spine Rev Rhum. 2003;70:276-81.

35. Thomas T, Amouroux F, Vincent P. Intra articular hyaluronic acid in the management of knee osteoarthritis: Pharmaco-economic study from the perspective of the national health insurance system. PloS One. 2017;12:e0173683.

36. Miller LE, Block JE. An 8-Week Knee Osteoarthritis Treatment Program of Hyaluronic Acid Injection, Deliberate Physical Rehabilitation, and Patient Education is Cost Effective at 2 Years Follow-up: The OsteoArthritis Centers of America(SM) Experience. Clin Med Insights Arthritis Musculoskelet Disord. 2014;7:49-55.

37. Mazières B, Bard H, Ligier M, Bru I, d'Orsay GG, Le Pen C. Medicoeconomic evaluation of hyaluronic acid for knee osteoarthritis in everyday practice: the MESSAGE study. Jt Bone Spine Rev Rhum. 2007;74:453-60.

38. Altman R, Alarcón G, Appelrouth D, Bloch D, Borenstein D, Brandt K, et al. The American College of Rheumatology criteria for the classification and reporting of osteoarthritis of the hip. Arthritis Rheum. 1991;34:505-14.

39. Altman R, Asch E, Bloch D, Bole G, Borenstein D, Brandt K, et al. Development of criteria for the classification and reporting of osteoarthritis. Classification of osteoarthritis of 
the knee. Diagnostic and Therapeutic Criteria Committee of the American Rheumatism Association. Arthritis Rheum. 1986;29:1039-49.

40. Ramsey S, Willke R, Briggs A, Brown R, Buxton M, Chawla A, et al. Good research practices for cost-effectiveness analysis alongside clinical trials: the ISPOR RCT-CEA Task Force report. Value Health J Int Soc Pharmacoeconomics Outcomes Res. 2005;8:521-33.

41. Ramsey SD, Willke RJ, Glick H, Reed SD, Augustovski F, Jonsson B, et al. Costeffectiveness analysis alongside clinical trials II-An ISPOR Good Research Practices Task Force report. Value Health J Int Soc Pharmacoeconomics Outcomes Res. 2015;18:161-72.

42. Hiligsmann M, Cooper C, Guillemin F, Hochberg MC, Tugwell P, Arden N, et al. A reference case for economic evaluations in osteoarthritis: an expert consensus article from the European Society for Clinical and Economic Aspects of Osteoporosis and Osteoarthritis (ESCEO). Semin Arthritis Rheum. 2014;44:271-82.

43. Hawkins N, Scott DA. Cost-effectiveness analysis: discount the placebo at your peril. Med Decis Mak Int J Soc Med Decis Mak. 2010;30:536-43.

44. Why Perspective Matters In Health Outcomes Research Analyses.pdf [Internet]. [cited 2018 Feb 6]. Available from: https://www.cluteinstitute.com/ojs/index.php/IBER/article/download/8186/8225

45. Massetti M, Aballéa S, Videau Y, Rémuzat C, Roïz J, Toumi M. A comparison of HAS \& NICE guidelines for the economic evaluation of health technologies in the context of their respective national health care systems and cultural environments. J Mark Access Health Policy. 2015;3.

46. Reginster J-Y. The efficacy of glucosamine sulfate in osteoarthritis: financial and nonfinancial conflict of interest. Arthritis Rheum. 2007;56:2105-10.

47. Laterre P-F, François B. Strengths and limitations of industry vs. academic randomized controlled trials. Clin Microbiol Infect Off Publ Eur Soc Clin Microbiol Infect Dis. 2015;21:906-9.

48. Black C, Clar C, Henderson R, MacEachern C, McNamee P, Quayyum Z, et al. The clinical effectiveness of glucosamine and chondroitin supplements in slowing or arresting progression of osteoarthritis of the knee: a systematic review and economic evaluation. Health Technol Assess Winch Engl. 2009;13:1-148.

49. Waddell DD. Viscosupplementation with hyaluronans for osteoarthritis of the knee: clinical efficacy and economic implications. Drugs Aging. 2007;24:629-42.

50. Dagenais S. Intra-articular hyaluronic acid (viscosupplementation) for knee osteoarthritis. Issues Emerg Health Technol. 2006;1-4.

51. Cooper C, Rannou F, Richette $\mathrm{P}$, Bruyère $\mathrm{O}$, Al-Daghri N, Altman RD, et al. Use of Intraarticular Hyaluronic Acid in the Management of Knee Osteoarthritis in Clinical Practice. Arthritis Care Res. 2017;69:1287-96. 
52. Guillemin F, Rat AC, Mazieres B, Pouchot J, Fautrel B, Euller-Ziegler L, et al. Prevalence of symptomatic hip and knee osteoarthritis: a two-phase population-based survey. Osteoarthritis Cartilage. 2011;19:1314-22.

53. Salmon JH, Rat AC, Sellam J, Michel M, Eschard JP, Guillemin F, et al. Economic impact of lower-limb osteoarthritis worldwide: a systematic review of cost-of-illness studies. Osteoarthritis Cartilage. 2016;24:1500-8.

54. Bijlsma JWJ, Berenbaum F, Lafeber FPJG. Osteoarthritis: an update with relevance for clinical practice. Lancet Lond Engl. 2011;377:2115-26.

55. Courties A, Gualillo O, Berenbaum F, Sellam J. Metabolic stress-induced joint inflammation and osteoarthritis. Osteoarthritis Cartilage. 2015;23:1955-65.

56. Richmond SA, Fukuchi RK, Ezzat A, Schneider K, Schneider G, Emery CA. Are joint injury, sport activity, physical activity, obesity, or occupational activities predictors for osteoarthritis? A systematic review. J Orthop Sports Phys Ther. 2013;43:515-B19.

57. Hiligsmann M, Cooper C, Arden N, Boers M, Branco JC, Luisa Brandi M, et al. Health economics in the field of osteoarthritis: an expert's consensus paper from the European Society for Clinical and Economic Aspects of Osteoporosis and Osteoarthritis (ESCEO). Semin Arthritis Rheum. 2013;43:303-13.

58. National Institute for Health and Care Excellence. Guide to the Methods of Technology Appraisal 2013 [Internet]. London: National Institute for Health and Care Excellence (NICE); 2013 [cited 2018 Feb 8]. Available from: http://www.ncbi.nlm.nih.gov/books/NBK395867/

59. Thokala P, Ochalek J, Leech AA, Tong T. Cost-Effectiveness Thresholds: the Past, the Present and the Future. PharmacoEconomics [Internet]. 2018 [cited 2018 Feb 9]; Available from: http://link.springer.com/10.1007/s40273-017-0606-1

60. Rawlins MD, Culyer AJ. National Institute for Clinical Excellence and its value judgments. BMJ. 2004;329:224-7.

61. Gafni A, Birch S. Incremental cost-effectiveness ratios (ICERs): the silence of the lambda. Soc Sci Med 1982. 2006;62:2091-100.

62. Cleemput I, Neyt M, Thiry N, De Laet C, Leys M. Using threshold values for cost per quality-adjusted life-year gained in healthcare decisions. Int $\mathbf{J}$ Technol Assess Health Care. 2011;27:71-6. 
Figure 1: Flowchart of the study 
Table 1: Methodological characteristics of the cost-effectiveness studies in knee $\mathrm{OA}$

\begin{tabular}{|c|c|c|c|c|c|c|c|c|c|c|c|c|c|}
\hline Author & Country & Sponsor & $\begin{array}{c}\text { OA } \\
\text { diagnosis }\end{array}$ & $\begin{array}{l}\text { Radiographic } \\
\text { OA }\end{array}$ & Type of study & $\begin{array}{c}\text { Time } \\
\text { horizon }\end{array}$ & $\mathbf{n}$ & $\begin{array}{c}\text { OA } \\
\text { outcome }\end{array}$ & $\begin{array}{c}\text { OA } \\
\text { outcome }\end{array}$ & Treatment & Control group & Perspective & $\begin{array}{l}\text { Year and } \\
\text { currency }\end{array}$ \\
\hline \multicolumn{14}{|c|}{ For disease modifying osteoarthritis drugs } \\
\hline $\begin{array}{l}\text { Fagnani, } \\
1998[23]\end{array}$ & France & $\begin{array}{l}\text { Pharma } \\
\text { industry }\end{array}$ & $\begin{array}{l}\text { Knee } \\
\text { and hip }\end{array}$ & NR & Trial-based & $\begin{array}{c}9 \\
\text { months }\end{array}$ & 207 & $\begin{array}{l}\text { Lequesne, } \\
\text { VAS } \\
\text { AIMS2, } \\
\text { NHP }\end{array}$ & $\begin{array}{l}\text { QALY } \\
\text { (Lequesne's } \\
\text { index) }\end{array}$ & Diacerein & $\begin{array}{c}\text { Usual care: } \\
\text { Physical therapy, NSAIDs, } \\
\text { acetaminophen, IACS, } \\
\text { DMOADs }\end{array}$ & Societal & FF 1995 \\
\hline $\begin{array}{l}\text { Bruyere, } \\
2009[24]\end{array}$ & International & $\begin{array}{l}\text { Pharma } \\
\text { industry }\end{array}$ & $\begin{array}{l}\text { ACR } \\
\text { knee }\end{array}$ & Yes & Trial-based & $\begin{array}{c}24 \\
\text { months }\end{array}$ & 622 & $\begin{array}{l}\text { HUI } 3 \text {, VAS } \\
\text { WOMAC }\end{array}$ & $\begin{array}{l}\text { QALY } \\
\text { (HUI 3) }\end{array}$ & $\begin{array}{l}\text { Chondroitine } \\
\text { sulphate }\end{array}$ & $\begin{array}{l}\text { Imposed care : } \\
\text { Placebo }\end{array}$ & Payer & $€ 2008$ \\
\hline $\begin{array}{l}\text { Scholtissen, } \\
2010[25]\end{array}$ & $\begin{array}{l}\text { Spain } \\
\text { Portugal }\end{array}$ & Academic & $\begin{array}{l}\text { ACR } \\
\text { knee }\end{array}$ & NR & Trial-based & $\begin{array}{c}6 \\
\text { months }\end{array}$ & 266 & $\begin{array}{l}\text { HUI } 3 \\
\text { WOMAC }\end{array}$ & $\begin{array}{l}\text { QALY } \\
\text { (HUI 3) }\end{array}$ & Glucosamine & $\begin{array}{l}\text { Imposed care : } \\
\text { Acetaminophen } \\
\text { or Placebo }\end{array}$ & Payer & $€ 2009$ \\
\hline $\begin{array}{l}\text { Losina, } \\
2013[26]\end{array}$ & US & Academic & Knee & Yes & Model-based & $\begin{array}{c}10 \\
\text { years }\end{array}$ & NR & QALE & QALY & All DMOADs & $\begin{array}{c}\text { Usual care: } \\
\text { Physical therapy, NSAIDs } \\
\text { and acetaminophen }\end{array}$ & Payer & \$US 2013 \\
\hline \multicolumn{14}{|c|}{ For intra-articular hyaluronic acid } \\
\hline $\begin{array}{l}\text { Torrance, } \\
2002[27]\end{array}$ & Canada & Academic & Knee & Yes & Trial-based & $\begin{array}{c}12 \\
\text { months }\end{array}$ & 255 & $\begin{array}{c}\text { HUI } 3 \\
\text { WOMAC }\end{array}$ & $\begin{array}{l}\text { QALY } \\
\text { (HUI 3) }\end{array}$ & Hylan G-F 20 & $\begin{array}{c}\text { Usual care: } \\
\text { Physical therapy, NSAIDs } \\
\text { and acetaminophen }\end{array}$ & Societal & \$CA 1999 \\
\hline $\begin{array}{l}\text { Kahan, } \\
2003[34]\end{array}$ & France & $\begin{array}{l}\text { Pharma } \\
\text { Industry }\end{array}$ & $\begin{array}{l}\text { ACR } \\
\text { knee }\end{array}$ & Yes & Trial-based & $\begin{array}{c}9 \\
\text { months }\end{array}$ & 506 & $\begin{array}{l}\text { Lequesne, } \\
\text { WOMAC, } \\
\text { SF-12 }\end{array}$ & $\begin{array}{l}\text { QALY } \\
\text { (Lequesne's } \\
\text { index) }\end{array}$ & Hylan G-F 20 & $\begin{array}{l}\text { Usual care: } \\
\text { Physical therapy, NSAIDs, } \\
\text { IACS and acetaminophen }\end{array}$ & Payer & $€ 1998$ \\
\hline $\begin{array}{c}\text { Yen, } \\
2004 \text { [28] }\end{array}$ & Taiwan & Academic & Knee & Yes & Model-based & $\begin{array}{c}6 \\
\text { months }\end{array}$ & 300 & VAS & $\begin{array}{l}\text { QALY } \\
\text { (VAS) }\end{array}$ & SH & $\begin{array}{c}\text { Imposed care: } \\
\text { Celecoxib } 100 \mathrm{mg} \mathrm{X} 2 \\
\text { or Naproxen } 250 \mathrm{mg} \mathrm{X} 3\end{array}$ & Societal & \$US 2002 \\
\hline $\begin{array}{c}\text { Chou, } \\
2009[29]\end{array}$ & Taiwan & Academic & $\begin{array}{l}\text { ACR } \\
\text { knee }\end{array}$ & Yes & Trial-based & $\begin{array}{c}6 \\
\text { months }\end{array}$ & 37 & $\begin{array}{l}\text { VAS, HSS } \\
\text { WOMAC }\end{array}$ & $\begin{array}{l}\text { QALY } \\
\text { (VAS) }\end{array}$ & Hylane G-F 20 & $\begin{array}{c}\text { Imposed care : } \\
\text { Sodium hyaluronate }\end{array}$ & Societal & \$NT 2006 \\
\hline $\begin{array}{l}\text { Hatoum, } \\
2014[30]\end{array}$ & US & $\begin{array}{l}\text { Pharma } \\
\text { Industry }\end{array}$ & $\begin{array}{l}\text { ACR } \\
\text { knee }\end{array}$ & Yes & Model-based & $\begin{array}{c}12 \\
\text { months }\end{array}$ & 214 & $\begin{array}{l}\text { HUI 3, } \\
\text { VAS } \\
\text { WOMAC }\end{array}$ & $\begin{array}{l}\text { QALY } \\
\text { (HUI 3) }\end{array}$ & SH & $\begin{array}{l}\text { Usual care: } \\
\text { Physical therapy, NSAIDs, } \\
\text { IACS and acetaminophen }\end{array}$ & Payer & \$US 2012 \\
\hline $\begin{array}{l}\text { Castro, } \\
2015[31]\end{array}$ & Colombia & $\begin{array}{l}\text { Pharma } \\
\text { industry }\end{array}$ & Knee & Yes & Model-based & $\begin{array}{c}20 \\
\text { years }\end{array}$ & 1000 & WOMAC & $\begin{array}{c}\text { QALY } \\
\text { (WOMAC) }\end{array}$ & Hylan G-F 20 & $\begin{array}{c}\text { Usual care: } \\
\text { Physical therapy, NSAIDs, } \\
\text { IACS } \\
\text { and acetaminophen }\end{array}$ & Societal & \$US 2015 \\
\hline $\begin{array}{l}\text { Rosen, } \\
2016[32]\end{array}$ & US & $\begin{array}{l}\text { Pharma } \\
\text { industry }\end{array}$ & $\begin{array}{l}\text { ACR } \\
\text { knee }\end{array}$ & Yes & Trial-based & $\begin{array}{c}6 \\
\text { months }\end{array}$ & $\begin{array}{c}30 \\
1038 \\
346\end{array}$ & $\begin{array}{l}\text { HUI 3, } \\
\text { VAS } \\
\text { WOMAC }\end{array}$ & $\begin{array}{l}\text { QALY } \\
\text { (HUI 3) }\end{array}$ & $\begin{array}{l}\text { Hylan G-F } 20 \\
\text { or SH } \\
\text { or NASHA }\end{array}$ & $\begin{array}{l}\text { Usual care: } \\
\text { Physical therapy, NSAIDs } \\
\text { and acetaminophen }\end{array}$ & Payer & \$US 2015 \\
\hline $\begin{array}{l}\text { Hermans, } \\
2017[33]\end{array}$ & Netherlands & Academic & Knee & Yes & Trial-based & $\begin{array}{c}12 \\
\text { months }\end{array}$ & 156 & EuroQol-5D & $\begin{array}{c}\text { QALY } \\
\text { (EuroQol-5D) }\end{array}$ & Hylan G-F 20 & $\begin{array}{c}\text { Usual care: } \\
\text { Physical therapy, NSAIDs } \\
\text { and acetaminophen }\end{array}$ & Societal & $€ 2010$ \\
\hline $\begin{array}{l}\text { Thomas, } \\
2017 \text { [35] }\end{array}$ & France & $\begin{array}{l}\text { Pharma } \\
\text { Industry }\end{array}$ & Knee & Yes & Case control & $\begin{array}{c}6 \\
\text { months }\end{array}$ & 401 & $\begin{array}{l}\text { EuroQol-5D } \\
\text { WOMAC }\end{array}$ & $\begin{array}{c}\text { QALY } \\
\text { (EuroQol-5D) }\end{array}$ & SH & $\begin{array}{l}\text { Imposed care : } \\
\text { NSAIDs }\end{array}$ & Payer & $€ 2014$ \\
\hline
\end{tabular}

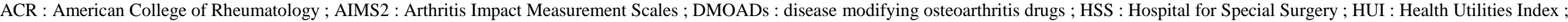

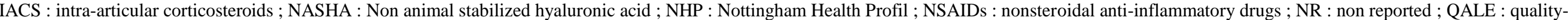

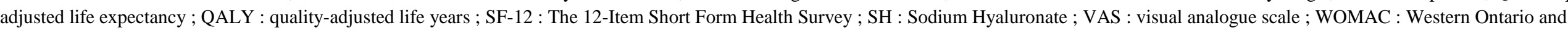

McMaster Universities Osteoarthritis Index 
Table 2: Results of the cost-effectiveness studies (in $€ 2017$ / QALY)

\begin{tabular}{|c|c|c|c|c|c|c|c|c|c|c|c|}
\hline Author & Treatment & Dosage & Control group & $\begin{array}{c}\text { Time } \\
\text { horizon }\end{array}$ & $\begin{array}{c}\text { Cost in the } \\
\text { Intervention arm }(€ \\
\text { 2017) }\end{array}$ & $\begin{array}{l}\text { Cost in the } \\
\text { Control arm } \\
(€ 2017)\end{array}$ & $\begin{array}{c}\Delta \\
\text { cost }\end{array}$ & $\begin{array}{l}\text { Effectiveness in the } \\
\text { Intervention arm } \\
\text { (QALY) }\end{array}$ & $\begin{array}{l}\text { Effectiveness in } \\
\text { the Control arm } \\
\text { (QALY) }\end{array}$ & $\begin{array}{c}\Delta \\
\text { incremental } \\
\text { effectiveness }\end{array}$ & ICER \\
\hline \multicolumn{12}{|c|}{ For disease modifying osteoarthritis drugs } \\
\hline $\begin{array}{l}\text { Fagnani, } \\
1998[23]\end{array}$ & Diacerein & $100 \mathrm{mg} / \mathrm{d}$ & $\begin{array}{c}\text { Usual care: } \\
\text { Physical therapy, NSAIDs, } \\
\text { acetaminophen, IACS, DMOADs }\end{array}$ & $\begin{array}{c}9 \\
\text { months }\end{array}$ & 490 & 470 & 20 & NA & NA & NA & NA* \\
\hline $\begin{array}{l}\text { Bruyere, } \\
2009[24]\end{array}$ & $\begin{array}{l}\text { Chondroitine } \\
\text { sulphate }\end{array}$ & $800 \mathrm{mg} / \mathrm{d}$ & $\begin{array}{l}\text { Imposed care : } \\
\text { Placebo }\end{array}$ & $\begin{array}{c}24 \\
\text { months }\end{array}$ & 405 & 655 & -250 & 0,097 & 0,072 & 0,025 & Dominant \\
\hline $\begin{array}{l}\text { Scholtissen } \\
2010[25]\end{array}$ & Glucosamine & $1500 \mathrm{mg} / \mathrm{d}$ & $\begin{array}{l}\text { Imposed care : } \\
\text { Acetaminophen } \\
\text { or Placebo }\end{array}$ & $\begin{array}{c}6 \\
\text { months }\end{array}$ & 45 & $\begin{array}{c}55 \\
5\end{array}$ & $\begin{array}{c}-10 \\
40\end{array}$ & NR & NR & $\begin{array}{l}0,01 \\
0,01\end{array}$ & $\begin{array}{c}\text { Dominant } \\
4,000\end{array}$ \\
\hline $\begin{array}{l}\text { Losina, } \\
2013[26]\end{array}$ & $\begin{array}{c}\text { All } \\
\text { DMOADs }\end{array}$ & NA & $\begin{array}{l}\text { Usual care: } \\
\text { Physical therapy, NSAIDs } \\
\text { and acetaminophen }\end{array}$ & $\begin{array}{c}10 \\
\text { years }\end{array}$ & NR & NR & 2300 & NR & NR & 0.04 & 57,550 \\
\hline \multicolumn{12}{|c|}{ For intra-articular hyaluronic acid } \\
\hline $\begin{array}{l}\text { Torrance, } \\
2002[27]\end{array}$ & Synvisc $®$ & 3 injections & $\begin{array}{l}\text { Usual care: } \\
\text { Physical therapy, NSAIDs } \\
\text { and acetaminophen }\end{array}$ & $\begin{array}{c}12 \\
\text { months }\end{array}$ & 2,845 & 1,890 & 955 & NR & NR & 0,071 & 13,450 \\
\hline $\begin{array}{l}\text { Kahan, } \\
2003[34]\end{array}$ & Synvisc ${ }^{\circledR}$ & 3 injections & $\begin{array}{l}\text { Usual care: } \\
\text { Physical therapy, NSAIDs, } \\
\text { IACS and acetaminophen }\end{array}$ & $\begin{array}{c}9 \\
\text { months }\end{array}$ & 1,070 & 1,070 & 0 & NA & NA & NA & NA* \\
\hline $\begin{array}{l}\text { Yen, } \\
2004[28]\end{array}$ & $\operatorname{Artz} ®$ & 5 injections & $\begin{array}{c}\text { Imposed care : } \\
\text { Celecoxib } 100 \mathrm{mg} \mathrm{X} 2 \\
\text { or Naproxen } 250 \mathrm{mg} \mathrm{X} 3\end{array}$ & $\begin{array}{c}6 \\
\text { months }\end{array}$ & 880 & $\begin{array}{l}715 \\
650\end{array}$ & $\begin{array}{l}165 \\
230\end{array}$ & 0,0031 & $\begin{array}{c}0 \\
0,0023\end{array}$ & $\begin{array}{c}0,0031 \\
0,008\end{array}$ & $\begin{array}{l}53,225 \\
28,750\end{array}$ \\
\hline $\begin{array}{l}\text { Chou, } \\
2009 \text { [29] }\end{array}$ & Synvisc ${ }^{\circledR}$ & 3 injections & $\begin{array}{c}\text { Imposed care : } \\
\text { Artz® }(5 \text { injections })\end{array}$ & $\begin{array}{c}6 \\
\text { months }\end{array}$ & 235 & 310 & -75 & 0,060 & 0,041 & 0,019 & Dominant \\
\hline $\begin{array}{l}\text { Hatoum, } \\
2014[30]\end{array}$ & Euflexxa® & 6 injections & $\begin{array}{l}\text { Usual care: } \\
\text { Physical therapy, NSAIDs, } \\
\text { IACS and acetaminophen }\end{array}$ & $\begin{array}{c}12 \\
\text { months }\end{array}$ & 1470 & 525 & 945 & 0,164 & 0,14 & 0,024 & 39,375 \\
\hline $\begin{array}{l}\text { Castro, } \\
2015[31]\end{array}$ & Synvisc® & $\begin{array}{c}1 \text { or } 2 \\
\text { injections /y }\end{array}$ & $\begin{array}{l}\text { Usual care: } \\
\text { Physical therapy, NSAIDs, IACS } \\
\text { and acetaminophen }\end{array}$ & $\begin{array}{c}20 \\
\text { years }\end{array}$ & 26,875 & 26,545 & 330 & 15.43 & 14.34 & 1.09 & 305 \\
\hline \multirow{5}{*}{$\begin{array}{l}\text { Rosen, } \\
2016[32]\end{array}$} & Euflexxa® & 3 injections & \multirow{5}{*}{$\begin{array}{l}\text { Usual care: } \\
\text { Physical therapy, NSAIDs } \\
\text { and acetaminophen }\end{array}$} & \multirow{5}{*}{$\begin{array}{c}6 \\
\text { months }\end{array}$} & 820 & 315 & 505 & 0,145 & 0,03 & 0,115 & 4,390 \\
\hline & $\operatorname{Artz}{ }^{\circledR}$ & 3 injections & & & 740 & 315 & 425 & 0,095 & 0,03 & 0,065 & 6,540 \\
\hline & Synvisc ® & 3 injections & & & 1,050 & 315 & 735 & 0,124 & 0,03 & 0,094 & 7,820 \\
\hline & Durolane ${ }^{\circledR}$ & 1 injection & & & 660 & 315 & 345 & 0,085 & 0,03 & 0,055 & 6,275 \\
\hline & Hyalgan ${ }^{\circledR}$ & 3 injections & & & 645 & 315 & 330 & 0,073 & 0,03 & 0,043 & 7,675 \\
\hline $\begin{array}{l}\text { Hermans, } \\
2017[33]\end{array}$ & Synvisc® & 3 injections & $\begin{array}{l}\text { Usual care: } \\
\text { Physical therapy, NSAIDs } \\
\text { and acetaminophen }\end{array}$ & $\begin{array}{c}12 \\
\text { months }\end{array}$ & 8655 & 8125 & 530 & 0,779 & 0,727 & 0,052 & 10195 \\
\hline $\begin{array}{l}\text { Thomas, } \\
2017 \text { [35] }\end{array}$ & Arthrum® & 3 injections & NSAIDs & $\begin{array}{c}6 \\
\text { months }\end{array}$ & 230 & 220 & 10 & NR & NR & 0,042 & 240 \\
\hline
\end{tabular}

IACS : intra-articular corticosteroids ; ICER : Incremental Cost-Effectiveness Ratio ; NA : not available ; NR : non reported ; NSAIDs : nonsteroidal anti- inflammatory drugs

* ICER was estimated $20 €$ per point gain on Lequesne's index 
Supplemental data: Risk of bias for included RCT studies

\begin{tabular}{|c|c|c|c|c|c|c|c|}
\hline For disease modifying osteoarthritis drugs & $\begin{array}{c}\text { Random } \\
\text { sequence generation } \\
\text { (selection bias) }\end{array}$ & $\begin{array}{c}\text { Allocation } \\
\text { concealement } \\
\text { (selection bias) }\end{array}$ & $\begin{array}{c}\text { Blinding of } \\
\text { participants } \\
\text { and personnel } \\
\text { (performance bias) }\end{array}$ & $\begin{array}{c}\text { Blinding of } \\
\text { assessment outcome } \\
\text { (detection bias) }\end{array}$ & $\begin{array}{l}\text { Incomplete } \\
\text { outcome data } \\
\text { (attrition bias) }\end{array}$ & $\begin{array}{c}\text { Selective } \\
\text { reporting } \\
\text { (reporting bias) }\end{array}$ & Other bias \\
\hline Fagnani, 1998 & low risk & low risk & low risk & low risk & low risk & low risk & high risk \\
\hline Bruyere, 2009 & low risk & low risk & low risk & low risk & low risk & low risk & high risk \\
\hline Scholtissen, 2010 & low risk & low risk & low risk & low risk & low risk & low risk & low risk \\
\hline Losina, 2013 & unclear risk & low risk & low risk & low risk & low risk & unclear risk & low risk \\
\hline
\end{tabular}

\begin{tabular}{|c|c|c|c|c|c|c|c|}
\hline For disease modifying osteoarthritis drugs & $\begin{array}{c}\text { Random } \\
\text { sequence generation } \\
\text { (selection bias) }\end{array}$ & $\begin{array}{c}\text { Allocation } \\
\text { concealement } \\
\text { (selection bias) }\end{array}$ & $\begin{array}{c}\text { Blinding of } \\
\text { participants } \\
\text { and personnel } \\
\text { (performance bias) }\end{array}$ & $\begin{array}{c}\text { Blinding of } \\
\text { assessment outcome } \\
\text { (detection bias) }\end{array}$ & $\begin{array}{l}\text { Incomplete } \\
\text { outcome data } \\
\text { (attrition bias) }\end{array}$ & $\begin{array}{c}\text { Selective } \\
\text { reporting } \\
\text { (reporting bias) }\end{array}$ & Other bias \\
\hline Torrance, 2002 & low risk & low risk & low risk & low risk & low risk & unclear risk & low risk \\
\hline Kahan, 2003 & low risk & low risk & low risk & low risk & unclear risk & low risk & high risk \\
\hline Yen, 2004 & unclear risk & low risk & low risk & low risk & low risk & low risk & low risk \\
\hline Chou, 2009 & low risk & low risk & low risk & low risk & low risk & low risk & low risk \\
\hline Hatoum, 2014 & low risk & low risk & low risk & low risk & low risk & low risk & high risk \\
\hline Castro, 2015 & low risk & low risk & low risk & low risk & low risk & low risk & high risk \\
\hline \multicolumn{8}{|l|}{ Rosen, 2016} \\
\hline - Karlsonn, 2002 & low risk & low risk & low risk & low risk & low risk & unclear risk & high risk \\
\hline - Atman, 2004 & unclear risk & low risk & low risk & low risk & low risk & unclear risk & high risk \\
\hline - DeCaria, 2012 & low risk & low risk & low risk & unclear risk & low risk & unclear risk & high risk \\
\hline - Day, 2004 & low risk & low risk & low risk & low risk & low risk & unclear risk & high risk \\
\hline - Altman, 2009 & low risk & unclear risk & unclear risk & unclear risk & low risk & unclear risk & high risk \\
\hline Hermans, 2017 & low risk & low risk & low risk & low risk & low risk & low risk & low risk \\
\hline
\end{tabular}

